\title{
BALANCING WORK AND FAMILY WITH TELEWORK? ORGANIZATIONNAL ISSUES AND CHALLENGES FOR WOMEN AND MANAGERS
}

\author{
Note de recherche réalisée par \\ Diane-Gabrielle Tremblay \\ Professeure et directrice de la recherche, Télé-Université
}

Note 2003-4

De la Chaire Bell en Technologies et organisation du travail

Direction de la recherche

Télé-Université

Université du Québec 


\title{
Balancing Work and Family with Telework? \\ Organizational Issues and Challenges for Women and Managers
}

\author{
Diane-Gabrielle Tremblay \\ Professor and Research Director \\ Télé-université \\ Université du Québec \\ 4750, avenue Henri Julien \\ Montréal, Québec, H2T 3E4 \\ E-mail: dgtrembl@teluq.uquebec.ca
}

Article paru dans Women in Management . Manchester: MCB Press. Volume 17 issue 3/4. pp157-170.

Keywords: telework, women, work organization, work-family balancing, employment

\section{Bio notes:}

Diane-Gabrielle Tremblay is professor in the Economics and Management department and Director of Research at Tele-university of the University of Quebec (Canada). She is also Cochair of the Bell Canada Chair in Technology and Work Organization. She has been invited professor at the European School of Management-Ecole supérieure de commerce de Paris, Université de Paris I-Sorbonne, and Université de Lille I in the 90's and in 2001. She is also associate professor at the Ecole nationale d'administration publique, in Montreal.

She has published many books, amongst which a Labour Economics and a Human Resources Management textbooks, and others on working time, work organization, and has published articles in various journals, amongst which Labour and Management in Development, Revue de gestion des ressources humaines, Revue internationale Gestion, Technologies de l'information et sociétés, Politique et management public, Economie et sociétés, Futuribles, Organisation et territoire, Géographie, économie et société. Her present research grants are on : work-family balancing, teamwork and careers in the Knowledge Economy, telelearning and virtual communities of practice.

She is also member of the executive committee of the sociology of work committee of the International Association and co-chair of the "social times" committee of l'Association internationale des sociologues de langue francaise. 


\begin{abstract}
This article presents a research on telework and deals with the following questions: Who are the teleworkers (sex, age, main socio-occupational categories)? What are the impacts of telework on work organization and working conditions, particularly for women, and in terms of work-family balance, since telework is sometimes presented as a solution to problems of reconciling work and family responsibilities. Finally, what is the level of satisfaction among teleworkers and why are they satisfied or dissatisfied with this system? Are there differences between various groups on this regard? We insist on the dimensions of working conditions and autonomy in telework and highlight the fact that there is a risk of polarization according to gender, women being more frequently in a situation where they have less autonomy than men in telework, although many also see telework in a positive way, as an "escape" from a bureaucratic work environment.
\end{abstract}


Telework and women:

Its Impacts on Work Organization, the Reconciliation of Work and Family Responsibilities, and Satisfaction

\section{Introduction}

\subsection{Background and Litterature Review}

The issue of telework has come to the forefront of debates on work organization and use of technology in the last decade. Many studies have tried to evaluate the number of teleworkers, although this is difficult because of the different definitions presented (Akyeampong, 2001; Akyeampong, 1997; Akyeampong and Siroonian 1993; Siroonian, 1993; Nadwodny, 1996 for Canada). Many other authors have been preoccupied with the management of teleworkers (Katz, 1987, Greengard, 1994, Pinsonneault, 1996, St-Onge et al., 2000; Chapman et al., 1995; Bussières et al., 1999). There has been much less work on actual working conditions of teleworkers, although Hafer (1992) indicated that some tasks were less appropriate for full time teleworkers because of isolation, St-Onge (2000) indicated that employer and colleagues' support was important, and Felstead and Jewson's book (2000) presents an overview of the issues and some results from a research they conducted in England, at about the same time as ours. There is an astonishingly important amount of normative management litterature on "how to manage telework and teleworkers", but there is little documented research on teleworkers' tasks and their possible evolution in that context, or on questions of autonomy or work organization, as well as on risks or issues related to the gender dimension. Felstead and Jewson's book (2000), which was published as we finished our own research is the only notable exception, since it sheds some light on these issues on the basis of British research. Our own research, and my personal interest in this research was therefore to shed light on these issues, which appear to have been too often overlooked, even while data indicates that women form the majority of teleworkers in many sectors of activity and countries.

\subsection{Research Question}

Our research on telework was carried out from autumn 1999 to autumn 2000 in Quebec (the French speaking, second largest, province of Canada). The research was coordinated by the Centre francophone de recherche sur l'informatisation des organisations (CEFRIO - the francophone centre for the computerization of organizations). Considering the existing litterature (for full litterature consulted, see the Cefrio website: www.cefrio.qc.ca/), our research was focused on the impacts of telework on work organization and working conditions. It is also important to present our definition of telework, since there are many, and to determine who are the teleworkers we are talking about. Therefore, this article deals with the following questions: Who are the teleworkers (sex, age, main socio-occupational categories)? What are the impacts of telework on work organization and working conditions, particularly for women, and in terms of work-family balance, since telework is sometimes presented as a solution to problems of reconciling work and family responsibilities. Finally, what is the level of satisfaction among teleworkers and why are they satisfied or dissatisfied with this system? Are there differences between various groups on this regard? 


\subsection{Structure of the paper}

The structure of the paper follows from these questions. In the section that follows (2.1), we will deal with the issue of the extent of telework in Quebec and Canada, since this has often been overestimated (Tremblay, 2001). We will then present the methodology (2.2) followed in the research. In section 3, we will present the personal characteristics of teleworkers (3.1), look at the type of tasks being done by teleworkers (3.2), and at their working conditions (3.3). We will finally address the issue of work organization and autonomy according to gender (3.4), which will lead us to deal with the issue of whether or not teleworking was a choice of the worker or whether the decision had to be taken with a superior, this being considered an indication of the degree of autonomy in the job. In the fourth section, we will deal with overall satisfaction of teleworkers, and with the advantages and the disadvantages of telework (4.1 and 4.2). Finally, section 5 will deal with risks and issues related to working conditions and autonomy, taking into account the gender dimension, which highlights a risk of polarization according to gender.

\section{The Extent of Telework and our evaluation}

\subsection{A Question of Definition}

The lack of a common definition of telework makes it difficult to quantify this phenomenon. In fact, according to the definition retained here, telework may cover diverse forms of electronic outworking either from home or elsewhere. The broader the definition, the greater the estimate of the number of teleworkers in a given country or region. The numerous examples provided by Felstead and Jewson (2000) show that, in effect, the state of knowledge on the extent of telework is difficult to determine because of the multiple definitions used in various studies. Moreover, many studies that provide data on the extent of telework or homeworking were not designed originally to study telework and thus the definitions are sometimes vague. This makes it difficult to determine exactly what type of teleworker is included in the figures.

Although telework generally refers to homeworking, various studies also refer to all the other forms of electronic outworking such as mobile work carried out in various locations outside the central office (by sales representatives, technicians, etc.), work by employees from a number of firms through telecentres or telecottages, and work by employees of the same firm in satellite offices. These two latter forms (the telecentre and satellite office) are apparently well developed in certain countries, especially the English-speaking ones, but they seem to be relatively rare in Quebec.

The status of the teleworker is also poorly defined. The term teleworker may apply to a full-time homeworker, which would also include a self-employed worker, but it may also include a parttime travelling teleworker or even a casual teleworker who occasionally works at home. The survey conducted as part of this research allowed us to identify the relative importance of these diverse realities, a topic that we will return to once we have described the state of knowledge on the extent of telework. While bearing in mind these problems in defining telework, which have been analyzed in more detail in Tremblay (2001), let us now examine some of the data on the extent of telework in Quebec and Canada.

The state of knowledge on the extent of telework in Canada reflects the definitional problems described above. The Labour Force Supplement on work arrangements, carried out in November 1991 and November 1995, gave rise to a number of analyses of the phenomenon of telework 
(Akyeampong and Siroonian, 1993; Akyeampong, 1997; Nadwodny, 1996; Statistics Canada, 1998). However, these data are already several years old, and the new structure of the Labour Force Survey has been implemented over 1996-1997, which may pose a problem of comparability. However, the most recent evaluation (Akyeampong and Nadwodny, 2001) indicates that the number of people working from home has increased slightly in the last few years, from $6 \%$ to $8 \%$, which seems to contradict many views that telework is a phenomenon that is growing rapidly, some seeing going as high as $17 \%$ in some countries (on this, see Tremblay, 2001). Previous publications had indicated however, based on the 1991 survey, that that 5.8\% of Canadian workers worked at home (Siroonian, 1993) and this figure was confirmed by data from the 1991 Census in which it was found that $6.2 \%$ of the employed labour force worked at home. It is interesting to note that the two last percentages are similar, which means that the measure is undoubtedly valid, although the definition is rather broad, and has changed in 1996 to give now a percentage of $8 \%$. On the other hand, it should be underlined that selfemployed workers were excluded from the percentage given for 1991 because, according to Akyeampong and Siroonian (1993), they, unlike salaried teleworkers, have more control over their work. Thus, according to a number of authors, the aspect of control over work seems to be important, although it is not dealt with directly in large national surveys like that of Statistics Canada referred to here. Nadwodny (1996) compared the figures from the Labour Force Supplement (based on a sample) with those of the 1981 Census and found that the percentage of teleworkers had doubled in those 10 years. The 2001 figures presented earlier indicate a new increase from roughly $6 \%$ to $8 \%$. However, we must keep in mind that it is somewhat difficult to compare the data over time.

Our own survey data deal with a specific group of teleworkers, that is those persons who responded to the following screening question designed to identify teleworkers: "By teleworker, we mean a person who carries out paid work at home, mainly by computer; generally this work is transmitted to a client or employer via the Internet or on a diskette." This broad definition includes self-employed workers. However, because our case studies refer only to salaried teleworkers working at home, and this represents a more "strict" definition of telework, most of the tables in this article will include only the salaried workers in the survey, that is, 210 teleworkers in the stricter sense of the term. To better compare the data gathered in our interviews, and because of the strong concentration of women in the full-time group of teleworkers, we will include available survey data that specifically concern the teleworkers working full-time in their homes.

\subsection{Methodology}

Our research on telework was carried out in three stages. The first stage involved gathering and analyzing existing documents and studies on the topic from Canada, the United States and Europe in order to draw a portrait of telework and its extent in Quebec and elsewhere (this stage of the research will not be dealt with in this article; see Tremblay, 2001). In the second stage, we developed a questionnaire and conducted a survey of the population in order to assess the extent of telework in Quebec, as well as the population's interest in telework. We thus identified a number of people who were engaged in telework and focused on their experience of telework as well as the advantages and disadvantages that they perceive. It should be noted that until now, very few studies have measured the extent of this phenomenon in Quebec nor is there a sufficient body of representative data on the reality of telework as experienced by those involved in it. This is a gap that we hope to fill with our survey results. Finally, we carried out case studies in six 
organizations, interviewing 63 teleworkers, their supervisors and a number of co-workers for a more qualitative in-depth view of the phenomenon.

We had hoped to achieve a certain level of diversity in the case studies. In reality, we mainly studied large and, for the most part, unionized organizations in these case studies. However, we were able to cover both private and public organizations, teleworkers who have access to advanced technologies, others who use intermediate or average levels of technology as well as organizations with different types of management (rather traditional vs. rather modern). In the case studies, we met various organizational actors associated with the telework program, that is, managers (immediate supervisors and those in charge of the program), teleworkers, unions, information technology managers as well as the teleworkers' co-workers. Through these interviews, we were able to gather information on both the individual, organizational and societal aspects of telework as well as on assessments of the telework program. These semi-structured, face-to-face interviews were based on a questionnaire guide. Most of the interviews with the teleworkers themselves took place in their homes. All the interviews were recorded and lasted from one and a half to two hours. A case study was produced for each of the participating organizations based on the analysis of the interviews essentially (available on the Cefrio website cited above). The data presented here are drawn from these last two stages of the study.

\section{Results from the research}

This section presents some results from our research, that is mainly answers to the issue of who are the teleworkers in terms of personal characteristics, type of tasks they do, and their working conditions.

\subsection{Personal Characteristics of Teleworkers}

Although the trend in teleworking is increasing, only approximately $4 \%$ of the 10,590 respondents in our telephone survey in Quebec said that they were teleworkers working with a computer, as our definition required. Of those who did, $58.8 \%$ were self-employed, $35 \%$ were non-unionized employees and $6.6 \%$ were unionized employees. Obviously, we used a precise definition of telework (see above), in particular, a definition that excluded people who do not use technological links. And although a number of articles and studies appear to indicate that the telework phenomenon is growing rapidly, it is interesting to note that our survey found that $60 \%$ of the teleworkers had been engaged in telework for more than two years, compared to only $11 \%$ for less than 6 months and $28 \%$ between 6 months and 2 years. These data may provide a clue as to the predictable growth of telework.

The following portrait emerges from our survey of salaried teleworkers:

There are more men $(58.8 \%)$ than women $(41.2 \%)$, although there are more women (67 $\%)$ when we consider only full time teleworkers;

Most teleworkers (70\%) are between 26 and 45 years old; $41.7 \%$ are between 35 and 45 years old;

$47 \%$ have a spouse and one or more children; $22.7 \%$ have a spouse but no children; $19.4 \%$ are single without children;

$60.6 \%$ of teleworkers have a university degree, $25.6 \%$ have a college diploma, and $12.5 \%$ have a high school diploma; these percentages reflect a higher level of schooling than those for the population as a whole. 
This portrait is similar to the one that emerges from the many studies cited in Felstead and Jewson (2000) as well as in Felstead, Jewson et al. (2000), who carried out a fairly exhaustive review of the body of literature published on the subject.

The following profile emerges for the teleworkers interviewed for our case studies:

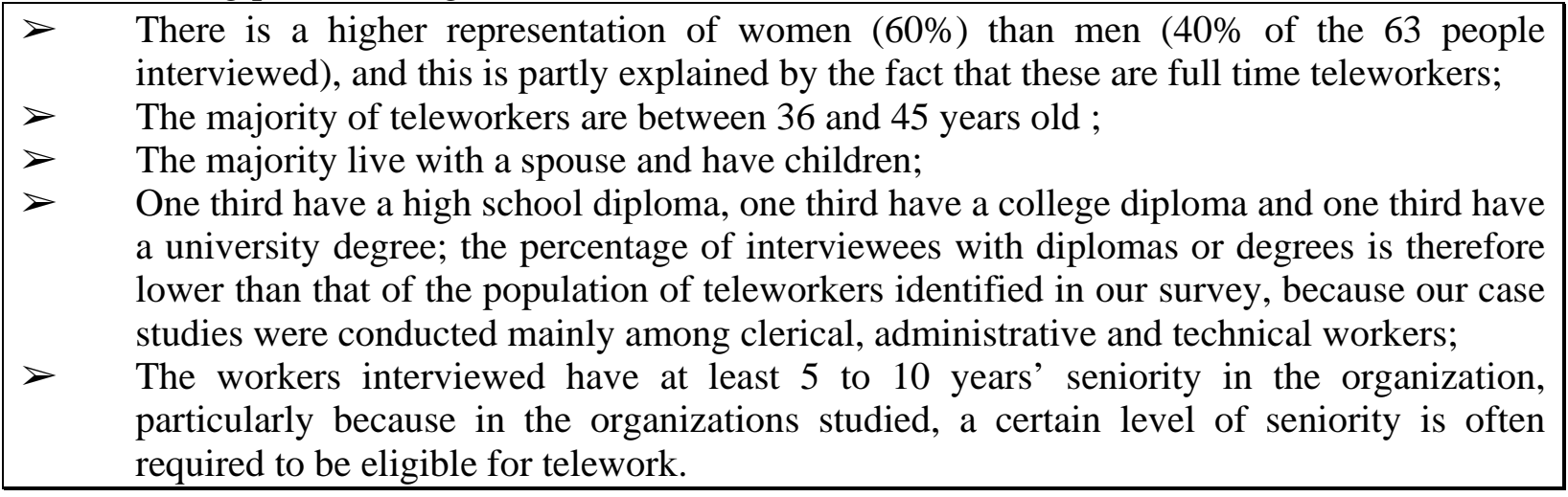

Although the majority of salaried teleworkers in our survey are men, this is not true of salaried teleworkers who work exclusively out of their homes. In $67 \%$ of the latter cases, these teleworkers are women. It is therefore important to consider these data in relation to the type of job held. It should be recalled that women are over-represented in our case studies because the majority of the jobs are those traditionally held by women (telephone operators, clerical workers, etc.). Thus, there is a pronounced gender-based differentiation of telework jobs. Most often, men hold the autonomous professional jobs and women hold salaried clerical jobs.

On the other hand, the survey and case study data on age and family status are similar. The majority of teleworkers in the case studies are between 35 and 45 years old and live with their spouse and children. The survey showed that individuals engaged in telework belong to this same age group, that is, between 26 and 45 years old, and a high proportion of these are aged between 35 and 45 .

\subsection{Type of Tasks}

The studies and articles on telework generally suggest that certain types of tasks lend themselves more to telework than do others (see Hafer, 1992 amongst others). However, our case studies seem to indicate that supervisors think that it is the characteristics of both the individual and the tasks which determine whether or not a situation is suited to telework.

In any event, our survey indicates that the tasks carried out by teleworkers at home have certain elements in common. In the case of individuals who carry out only a part of their work at home (executives and managers), administrative tasks, writing, accounting and other tasks tend to be carried out at home. Many of the other tasks carried out at home are done by computer, in particular tasks related to management of information, software and Web site design or computer graphics. The latter is often carried out by self-employed teleworkers, as is also the case for accounting, writing or wordprocessing. 
Table 1. Tasks Carried Out by Teleworkers

\begin{tabular}{|l|l|l|}
\hline Type of task & Self-employed & Salaried \\
\hline Writing and word processing & $23.5 \%$ & $35.1 \%$ \\
\hline Accounting & $17.5 \%$ & $18.55 \%$ \\
\hline Management/administration & $10.2 \%$ & $16.6 \%$ \\
\hline Software and Web site design & $14 \%$ & $11.4 \%$ \\
\hline $\begin{array}{l}\text { Sending, receiving and } \\
\text { processing electronic mail }\end{array}$ & $6.7 \%$ & $15.2 \%$ \\
\hline CAD, computer graphics & $15.1 \%$ & $2.8 \%$ \\
\hline Translation & $8.8 \%$ & $0.9 \%$ \\
\hline
\end{tabular}

According to Hafer (1992), restrictions on the type of job suited to telework apply particularly to full-time telework. However, according to the same author, many jobs can be done through telework if the employee is absent from the office only one or two days per week. Although telework is more appropriate for a job based on an individual contribution, part-time telework may also be suited to jobs in which team work is required but which include tasks that can be done outside the office. The new electronic data exchange technologies that allow collaboration from multiple locations (groupware, Netmeeting and other group collaboration software) may facilitate this form of team work, but few workers have this technology and it seems unlikely that this will develop, especially in clerical jobs where telework is often aimed at a greater concentration and isolation of individuals.

\subsection{Working Conditions}

Felstead and Jewson (2000; and Felstead, Jewson et al., 2000) note that there are often differences in working conditions between teleworkers and the rest of the organization's employees. This may be surprising and certainly does not seem to apply to unionized environments such as the ones in our case studies. However, since the majority of telework jobs are non-unionized, it is reasonable to ask whether or not Felstead and Jewson's observations for England and other countries that they have studied would hold for Quebec.

The following data on employment-related working conditions emerge from the survey:

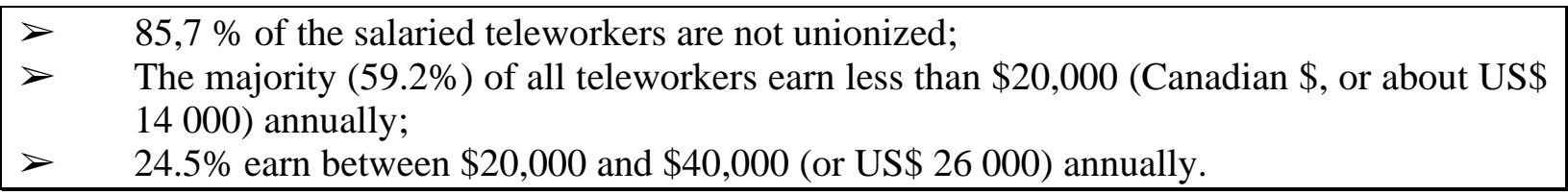

The survey results relating to the salaries of teleworkers are somewhat surprising. Despite the fact that the majority of respondents who stated that they were teleworkers are executives or professionals with a university degree, $59.2 \%$ stated that they earn an income of less than $\$ 20,000$ (Canadian). One possible explanation for this is that a quarter of teleworkers are employed in firms with less than 10 employees and many are self-employed $(58,8 \%)$. This may explain both the low unionization rate as well as the low salary levels of those surveyed. A second explanatory factor may be the number of hours worked per week, on which we do not have precise 
information since we had to limit the number of questions asked in the telephone survey. However, all of the individuals interviewed in the case studies work at home on a full-time basis, and their salaries are significantly higher; they also work for large unionized organizations, large high-tech firms or the public sector, organizations in which salaries are generally higher than those in small private firms. Seniority may also be a factor, however we do not have data on this. A final explanatory factor may be the specific occupational category of these teleworkers. In particular, as the following data on income show, secretarial jobs and those in Web site design are generally poorly paid.

50 to $60 \%$ of teleworkers in the fields of information technology and Web site design,
editing and layout earn less than $\$ 10,000$;
$66.7 \%$ of teleworkers in the secretarial field earn less than $\$ 10,000 ;$
$37 \%$ of teleworkers in the management field earn between $\$ 10,000$ and $\$ 20,000$ and
$22.2 \%$ earn between $\$ 20,000$ and $\$ 30,000$.

A comparison of the salaries reported in the case studies shows that the majority of the clerical teleworkers, most of whom are at the end of their career, earn between CAN\$30,000 and CAN $\$ 40,000$ while the executives and professionals earn approximately CAN $\$ 60,000$ (or US $\$ 40$ 000). These salaries can be partly explained by the seniority of teleworkers within the organization. On the other hand, an explanation for the low income level reported by managers in the survey has yet to emerge (beyond the idea that these teleworkers, especially the self-employed may have under-reported their income, or reported their net income instead of the gross income).

\subsection{Work Organization and Autonomy of Teleworkers differentiated according to gender}

If we examine telework and homeworking in general, without limiting our analysis to workers who use a computer or electronic link, a quite varied portrait of this work force emerges from the studies on this topic. Few theoretical studies make distinctions between the various categories of outworking. One exception is the study by Felstead and Jewson (2000: 16) who, dissatisfied with the prevailing empiricism of most studies and articles on telework, developed their own typology.

They divide all homeworkers into two groups: employers who work at home (or self-employed workers with employees) and workers (who do not have employees) who work at home. The latter group is subdivided into two groups: those who have a direct link with the final user of their product (for example, self-employed workers on contract) and those who sell their work to a supplier, intermediary or employer. The latter group is again subdivided into two: those who have considerable discretion or autonomy in their work, that is, professionals and executives, and those who have little autonomy or discretion (routine manual or service jobs, such as clerical workers, secretaries, etc.). Our study focused on salaried teleworkers, that is, the latter two groups in the typology and, in fact, the same type of distinction was found according to the degree of autonomy exercised by individuals in their decision to undertake telework and in the tasks that they carry out.

In addition to teleworkers' occupational category, which is often used as an indicator of degree of autonomy, the way in which the decision to do telework is made is an element that can be used to characterize degree of autonomy or discretion. Thus, the possibility of making one's own 
decision reflects a degree of autonomy, while having to make the decision jointly with an employer reflects a more limited degree of autonomy.

Thus, $48.6 \%$ of all the survey respondents made the decision to do telework jointly with their employer while $45.8 \%$ made the decision on their own. According to the survey results, telework was imposed by employers on only $5.1 \%$ of respondents, which is confirmed by the data from our case studies, in which all the subjects had made the decision to do telework voluntarily. It should be noted that telework in the organizations is suggested on a voluntary basis and that the employee must first decide whether or not he or she would like to do telework. On the other hand, in the majority of cases, teleworkers are selected according to a number of criteria such as seniority in the organization, level of performance, type of task and so on; in fact, the final decision often rests with the immediate supervisor even when it is said to be a joint decision. The immediate supervisor may in effect refuse to allow a person to opt for telework if he or she thinks that this employee does not have the required skills or attitudes.

The survey data confirm that executives and professionals have greater autonomy ${ }^{1}$ in their decisions regarding telework: $58 \%$ of the executives and $47.4 \%$ of the professionals made the decision on their own while $85.7 \%$ of the clerical workers made the decision jointly with their employer. The data according to gender reflect occupational segregation: 55.9\% of men made the decision on their own while $64 \%$ of women made the decision jointly, more frequently with their superior. This highlights even more strongly the fact that there exists a profound gender-based differentiation of telework jobs.

Examination of the family status of the teleworkers in our study reveals that the majority have a spouse and one or more children $(47.2 \%)$ or are single parents $(7.4 \%) ; 54.9 \%$ of the respondents who have a spouse and one or more children made the decision to do telework independently while $62.5 \%$ of the single parents made this decision jointly. The case studies confirm that telework is more attractive for those who have a spouse and children because it allows them to reduce their travel time, to be at home later in the morning and earlier in the evening, and thus to achieve a better balance between work and family responsibilities. The interviews revealed that fewer single people opt for this form of work, particularly because it would result in greater isolation for them and possibly less career opportunities, since many managers are not accustomed to manage from a distance and keep the absentees in mind, as revealed in some interviews. However, single people without children make up $19.4 \%$ of all of the teleworkers surveyed (42 out of 216).

\footnotetext{
${ }^{1}$ On the concept of autonomy, see Tremblay and Rolland $(1998,2000)$.
} 
Table 2. Type of Decision According to Family Status of Teleworkers (vertical \%)

\begin{tabular}{|l|l|l|l|l|l|}
\hline Type of decision & $\begin{array}{l}\text { Single } \\
\text { parent }\end{array}$ & $\begin{array}{l}\text { Single } \\
\text { without } \\
\text { child- } \\
\text { ren }\end{array}$ & $\begin{array}{l}\text { Spouse } \\
\text { with } \\
\text { child(ren) }\end{array}$ & $\begin{array}{l}\text { Spouse } \\
\text { without } \\
\text { children }\end{array}$ & Other cases \\
\hline $\begin{array}{l}\text { Decision imposed by } \\
\text { employer }\end{array}$ & $6.3 \%$ & $7.1 \%$ & $2.9 \%$ & $8.2 \%$ & $2.8 \%$ \\
\hline Personal decision & $31.2 \%$ & $57.1 \%$ & $54.9 \%$ & $24.5 \%$ & $33.3 \%$ \\
\hline Joint decision & $62.5 \%$ & $35.7 \%$ & $41.2 \%$ & $67.3 \%$ & $66.7 \%$ \\
\hline
\end{tabular}

Of the 216 salaried teleworkers interviewed by phone, $73.1 \%$ stated that they did not have any formal agreement with their employer regarding working conditions. Only $26.4 \%$ had signed an agreement. Thus, $80.2 \%$ of the executives and managers had not signed an agreement and it is known that the majority of them had simply made the decision on their own. It should be noted that most managers and executives work at home only one day per week $(51.8 \%$ spend under $20 \%$ of their work time at home). As for professionals, $30.3 \%$ have an agreement with their employer, compared with $69.7 \%$ who do not. Finally, $28.6 \%$ of the clerical employees have an agreement, compared to $71.4 \%$ who do not. Thus, telework is mainly based on informal agreements or individual personal decisions.

These data differ from those collected for our case studies since the great majority of teleworkers interviewed in the case studies had signed an agreement (though some of them could not recall the details of the terms of agreement.) Generally, these agreements clearly describe the conditions in which the telework must be carried out and may include work schedules, security measures to be adopted to safeguard the confidentiality of information and data as well as the conditions for returning to work in the office. Generally speaking, they do not contravene the collective agreements, except in certain cases where the teleworker may be required to maintain a level of productivity that is equal to or higher than that required of workers in the office (up to $20 \%$ in some cases, we were told)

Given that most of the professionals and executives in the case studies do telework on an occasional or part-time basis under conditions that do not appear to be as strict, they generally do not sign a specific agreement; the majority of these are male workers, although about a third are female. The survey results indicate that the larger the firm, the greater the likelihood that the teleworker has an agreement with his or her employer. In fact, $36.8 \%$ of the teleworkers who signed an agreement work for a firm with 500 or more employees, $22.8 \%$ work for a firm with 10 to 15 employees and $12 \%$ work for a firm with between 200 and 500 employees.

Data analyzed according to activity sector indicate that:

$>\quad 65 \%$ of teleworkers with an agreement work in the services sector;

$>\quad 26 \%$ are in the public sector;

$>\quad 7 \%$ are employed in the manufacturing sector.

As regards work organization, our case studies indicate that teleworkers feel that they have a fair degree of freedom in their work, even though some of them may be monitored from a distance 
through the computerized systems that they use to carry out the work. In fact, although the practice appears to be infrequent, the connect time of a number of respondents is monitored.

Felstead and Jewson (2000) have also raised the possibility that telework can create a differentiation of tasks between those who work in the office and those who work at home. Indeed, our case studies revealed a number of interesting factors regarding the content of work and its evolution in the context of telework. For example, the findings from our interviews indicated that most teleworkers (two-thirds of the 63 people interviewed) basically do the same work at home as they do in the office. However, several of those interviewed thought that they had more autonomy in solving problems that arise while working and have even been able to acquire new skills and knowledge since they have had to manage on their own at home whereas at the office they might have consulted a co-worker.

However, it should be noted that the tasks of 20 of the 63 teleworkers (or a third) in the three different organizations were changed. Different situations were observed, including certain cases in which the content of the work carried out is less prestigious, in their own view, in the sense that the teleworkers work with a less prestigious market segment than those who still work in the office (for example, the teleworkers work with individuals as opposed to business customers). In other cases, the content of work is less varied since the telework tasks to be carried out must be more defined. These two situations are rather negative in terms of the content of tasks and the possibility of developing new skills and knowledge and they often seem to concern women. On the other hand, some of the teleworkers dropped certain less interesting tasks, such as printing and sorting of documents, since they transmit their documents by e-mail to the office where these tasks are carried out by the workers located there. Thus, the differentiation of work content or division of labour between teleworkers and office workers is clearly an important factor to consider when developing telework, although male technicians are also concerned in one case.

Since there are rarely specific agreements in this regard, changes sometimes occur "naturally," without a specific decision having been made to change tasks in one direction or another (diversification or standardization of tasks, deskilling or reskilling). However, it must certainly be considered since both the teleworkers and those who remain in the office may either complain about such changes or welcome them, depending on the case. In broader social terms, these aspects should be considered because of the increasing attention given these days to concepts such as the learning organization, the importance of challenges and training for maintaining the motivation of individuals at work, and developing innovation and creativity within the organization. This suggests that these factors should always be examined before proceeding with a telework project.

What is especially important to retain from this section is that our results clearly show that working conditions, autonomy and discretion in work, as in the decision to do telework, are differentiated according to occupational category and gender. Female teleworkers are more concentrated in accounting, translation, word processing and secretarial work and the decision to do telework is more often made jointly with their employer, their supervisor's opinion often being quite determinant. In contrast, male teleworkers are more concentrated in executive, management, professional and technical positions and they are more likely to have made the decision to do telework on their own; some women are also in these categories and have the same advantages but they are less numerous than their male counterparts (let us recall that women represent about a third of the managerial category in Canada). This confirms that, like the labour 
market in general, the telework market is segmented. Since many of the studies on telework examine only one occupational category or one firm, few of them have examined this particular aspect of teleworking, except for Feldstead and Jewson (2000) which we received at the end of our own research and which confirms our finding of a form of segmentation in telework.

\section{Teleworkers' Overall Satisfaction}

Since the vast majority of teleworkers do telework voluntarily ( $94 \%$ of survey respondents), their general level of satisfaction is high as shown by the following results:

Table 3. Teleworkers' Level of Satisfaction

\begin{tabular}{|l|l|l|}
\hline Level of satisfaction & All salaried teleworkers & $\begin{array}{l}\text { Full-time salaried home } \\
\text { teleworkers }\end{array}$ \\
\hline Very satisfied & $63.4 \%$ & $68.0 \%$ \\
\hline Somewhat satisfied & $34.0 \%$ & $28.0 \%$ \\
\hline Somewhat dissatisfied & $1.6 \%$ & $4.0 \%$ \\
\hline Very dissatisfied & $1.0 \%$ & $0 \%$ \\
\hline
\end{tabular}

These very high levels of satisfaction were also found in the case studies. As mentioned above, if offered the chance, the vast majority of teleworkers interviewed would refuse to return to a traditional office. Some of them would even contemplate stopping work, especially those close to retirement age. Middle-aged teleworkers would return to the office if obliged to, but this would have major repercussions on their motivation. Many women felt there were no career opportunities in any case and therefore felt it was preferable to take advantage of the opportunity to work at home and save time from traffic. Quality of life is an important dimension in women's evaluation of telework. Many say they would even refuse a pay increase in order to keep on working from home; these persons either have no career aspirations, or are close to retirement, or consider the office environment difficult, and like to save money on lunch and transportation by staying at home.

Other variables in the survey indicate that there is an important link between the time spent doing telework and level of satisfaction and this also has a gender dimension, since women more frequently work full time at home, and are therefore somewhat less satisfied. Indeed, the $81.3 \%$ of teleworkers who spend 20 to $30 \%$ of their time doing telework have the highest level of satisfaction (very satisfied), followed by $68 \%$ of full-time home teleworkers. It should be recalled that our case studies revealed that telework appears to be particularly attractive to those women who carry out routine, repetitive work in a noisy environment and that requires little contact with co-workers. On the contrary, for those with career aspirations, it appears preferable to be visible in the office.

On the other hand, as shown in table 4 , satisfaction levels do not appear to be linked to whether or not teleworkers have a contract (whether formal or not) with their employer. This finding contradicts some of the management literature that suggests that it is preferable to have a formal agreement. In our case studies, some said that formal agreements sometimes lead to "dissecting" the job and the formalization can also foster jealousy in the workplace since some are clearly excluded because of formal criteria for selection of teleworkers. Informal agreements can also have their own disadavantages, in that they may lead to a lack of equitable access and to favouritism or arbitrary decisions as to who can or cannot benefit from telework. 
Table 4. Satisfaction Level According to Whether or Not There Is an Agreement

\begin{tabular}{|l|l|l|}
\hline Satisfaction level & $\begin{array}{l}\text { All teleworkers who } \\
\text { have an agreement }\end{array}$ & $\begin{array}{l}\text { All teleworkers who } \\
\text { do not have an } \\
\text { agreement }\end{array}$ \\
\hline Very satisfied & $58.1 \%$ & $67.8 \%$ \\
\hline Somewhat satisfied & $37.2 \%$ & $30.6 \%$ \\
\hline $\begin{array}{l}\text { Somewhat } \\
\text { dissatisfied }\end{array}$ & $4.7 \%$ & $0.8 \%$ \\
\hline Very dissatisfied & - & $0.8 \%$ \\
\hline
\end{tabular}

\subsection{Advantages of Telework}

The following table shows what the teleworkers in our survey considered to be the primary advantages of teleworking. The results are presented for all salaried teleworkers and for salaried, full-time home teleworkers (mostly women in this last case).

Table 5. Advantages Linked to Telework

\begin{tabular}{|l|l|l|}
\hline Advantage & Total salaried teleworkers & $\begin{array}{l}\text { Full-time } \\
\text { teleworkers }\end{array}$ \\
\hline 1. More flexible schedules & $29.1 \%$ & $44.9 \%$ \\
\hline $\begin{array}{l}\text { 2. Avoid travelling to the } \\
\text { office }\end{array}$ & $22.4 \%$ & $20.0 \%$ \\
\hline 3. More productive & $7.3 \%$ & $4 \%$ \\
\hline $\begin{array}{l}\text { 4. Can be close to their } \\
\text { family }\end{array}$ & $4.2 \%$ & $4 \%$ \\
\hline $\begin{array}{l}\text { 5. Improve the quality of } \\
\text { their work }\end{array}$ & $3.6 \%$ & $4 \%$ \\
\hline
\end{tabular}

It may be surprising for some to note that being close to the family is not the main motivation, considering the importance of this perspective in the litterature, but it can also be considered that flexible schedules and the possibility to avoid travelling to work have a positive influence on work-family balancing, as many pointed out. The case study results also indicated that workhours flexibility is an important advantage for many teleworkers, even if some of them do not take advantage of it, particularly women doing telephone work for call centres and the like. However, in the latter case, despite everything, women think that not having to travel is advantageous and that it simplifies their life in general and their family life in particular.

While some authors cite the ability to balance work and family responsibilities as an advantage of telework, others indicate that telework creates the risk of greater conflict between work and the family. In our survey, the reconciliation of work and family responsibilities does not emerge clearly as a major advantage. In another survey, we found that flexible schedules are rarely offered by private sector firms although this is an important aspiration of parents (Tremblay, 2001a, Tremblay and Vaillancourt, 2000); indeed, fewer than one in five firms offered work-time allocation or flexible schedules (Tremblay and Amherdt, 2000) and thus it is easy to understand why they would be regarded as a significant advantage by the teleworkers who have them. On the 
other hand, it can be said that benefiting from more flexible schedules and avoiding travel to the office can facilitate the work-family balance. In fact, the interviews revealed that the great majority of teleworkers think that this gives them more time with their family in the morning and evening, and makes them more available to meet their children's needs, to get them ready for day care or school in the morning and to attend to them even if it means working again later. Several of the teleworkers interviewed said that they were able to fit in household tasks during the work day, thus freeing up more time for themselves on the weekend.

Thus, while some of the literature emphasizes the risks of increased conflict between work and family responsibilities for teleworkers, the people we interviewed said that they had established rules and managed to identify an office space for themselves that was respected by the family. The first weeks or months had sometimes been more difficult but, after an adjustment period, both their spouse and children seemed to have understood that their telework parent was indeed working. However, it should be noted that Felstead and Jewson (2000) seem less optimistic in this regard, maintaining that women often find it harder to make family members understand that they are working at home and that they should not necessarily be expected to integrate all household tasks into their work schedule. The authors indicate that access to time and space at home may be subject to more difficult, negotiations and adjustments, more often in the case of women. While this was not reflected in our cases studies, it should be noted that many of these teleworkers were older and at the end of their career when balancing work and family responsibilities is perhaps less of a problem since their children are most likely beyond the critical years.

Moreover, while studies on the work-family balance increasingly point to the difficulties associated with taking care of sick family members or persons with disabilities, this type of problem did not show up in any of our case studies. Nor did the care of elderly or sick family members emerge as a significant problem in a previous study on the work-family balance (Tremblay and Vaillancourt, 2000). The data on aging (Bellemare, Poulin Simon and Tremblay, 1998) as well as many other studies suggest that this is a problem, but to date we have not been able to confirm that some people may see telework as a solution to this type of problem.

\subsection{Difficulties or dissatisfactions}

There was little dissatisfaction highlighted in the survey, but the case studies showed that the greatest source of dissatisfaction among teleworkers is related to technology. Several mentioned the slowness of computer systems and telephone lines and cumbersome security measures, even though this security aspect was considered to have improved over the years. However, this situation hampers the performance of teleworkers and may lead to a surplus of work for those located in the office. The teleworkers also expressed some dissatisfaction, although to a lesser degree, with their supervision and training. Several thought that there should be specific training for teleworkers, including training in time management, work organization (to meet deadlines) and in computer and communications systems.

Respondents to the survey most often mentioned the lack of co-workers and isolation $(15.4 \%$ and $10 \%$ of respondents) as disadvantages, followed by the risk of working more (9\%), the difficulty of motivating themselves (6\%) and work-family conflict (5\%). However, it should be noted that $26 \%$ of respondents thought that there were no inconveniences in teleworking, compared to $20 \%$ 
of the full-time home teleworkers, $24 \%$ of whom thought that not having co-workers was a disadvantage (it should be recalled that most of the full-time home teleworkers are women).

\subsection{The Views of Teleworkers - Conclusion}

The intensification of work linked, depending on the case, to tighter and tighter deadlines, a more aggressive search for clients and the development of new activities, is increasingly motivating employees to seek working conditions that are less stressful than those prevailing in the office. In this context, telework is sometimes seen as an attractive option. As Vandercammen (1996) points out, for some, the improvement of working conditions is not so much a matter of reducing work time, but of "de-intensifying" work. Indeed, studies show that many workers, particularly women office workers, are not in a position to reduce their work time when it would result in a proportional reduction in salary (Tremblay and Vaillancourt-Laflamme, 2000). Telework thus appears to be a way to avoid workplace stress, or at a minimum, to reduce it without incurring a salary loss.

Our case study findings nevertheless showed that telework had intensified as well, but in a more pleasant work environment which, according to the teleworkers interviewed, helped them produce more in the same amount of time. Indeed, they pointed out that the impression of a heavier work load did not always come from an additional burden imposed by the employer, even though several employers did, in fact, require a higher level of productivity. Conversely, the impression of a reduced work load at home, in their opinion, was due to a work environment that was more conducive to a higher level of production.

Moreover, the individualization of service provided by teleworkers sometimes leads firms to introduce productivity and performance standards that are different from those applied to other employees. Our interviews revealed that, in fact, firms required performance levels that were 10 to $20 \%$ higher than those required of other employees and that teleworkers agreed to these conditions despite warnings from their unions. As was mentioned above, it seems that they consider this an acceptable price to pay to have a more pleasant work environment, to escape the office and bureaucracy, and to reduce travel time and time spent in traffic jams.

\section{Risks or Issues Involved in Telework}

This section will examine the risks and issues involved in telework, particularly from the point of view of women who make up the majority of full-time home teleworkers.

\subsection{Impact on Employment and Working Conditions}

There is no legislation to cover the specific case of telework or to ensure that the working conditions of teleworkers are the same as those of other employees. This situation could result in a gradual polarization of workers, and this polarization could be along gender lines, as already seems to be the case with full time and part time teleworkers. As was mentioned above, this polarization may be particularly harmful for women by creating less attractive work content and working conditions. Felstead and Jewson (2000) report on studies that indicate that there is currently a differentiation between teleworkers and other employees but this did not emerge clearly in our study, although we did find gender differences. The risks of the job becoming more 
precarious should nevertheless be considered in a context in which the salary and working conditions of many new self-employed workers are inferior to those of workers who previously had comparable positions in the firm.

It was mentioned above that certain organizations differentiate between the tasks offered to teleworkers and those offered to employees located at the firm. This can be justified for all sorts of reasons (confidential data, the need for team work or for more regular monitoring of certain tasks, etc.), but the risk of task differentiation is certainly high. It was observed that in certain organizations, the teleworkers carry out more long-term, complex and interesting tasks while in other cases (which were found more frequently by Felstead and Jewson, 2000), their tasks were simpler, more repetitive and easier to measure.

In this sense, telework merely reflects what is happening on the labour market more generally, that is, the increasing segmentation or division between a core of stable, well-paid jobs and nonstandard jobs that are often precarious and poorly-paid. This is one of the potential risks of telework of which the state and society should be aware.

New information and communication technologies may accelerate the use of sub-contracting and self-employment outside the firm. The absence of protection from governments for this category of workers may result in them being abused. Even if there is a high proportion of teleworkers among professionals and white-collar workers, office workers are more likely to find themselves in a less advantageous position for negotiating their working conditions. Many authors ${ }^{2}$ fear that telework will be used to exploit a less skilled work force. It should therefore be recommended that the state, in particular its departments and statistical agencies concerned with employment, pay close attention to developments in this area because of the effects for individuals, but also because of the macro-economic effects of a deterioration of working conditions, particularly wage conditions.

\subsection{Gender-Based Polarization of Working Conditions}

The examination of the quality of telework jobs from the point of view of employment equity or equal opportunity showed that the great majority of women carry out office work that is often rather repetitive and routine. Although Vandercammen (1996) as well as Felstead and Jewson (2000) maintain that telework does not improve the content of tasks, our case studies, in contrast, revealed that, for most workers, monotonous and low-status jobs become much more tolerable in the context of telework. Moreover, one of the organizations that we studied recommends telework as a more attractive option for retaining and attracting employees in this type of work, which tends to be repetitive. For female managers however, it often seems preferable to work only part time in telework, as is the case for men, at least if they have career aspirations.

Telework could thus serve as a measure to retain the work force, not only now, but especially in the future, since many organizations foresee recruitment problems in the future. In this regard, in societal terms, it should be recommended that efforts be made to improve the working conditions of the female work force by enriching certain tasks rather than returning women to their homes simply to make their tasks more tolerable. A gender-based segmentation of working conditions

\footnotetext{
${ }^{2}$ Chapman et al., 1995, Christensen, 1992, Huws 1994, Olson 1988, Pratt 1984.
} 
already exists and it is true that women have benefited less from the growth in team work, autonomy and multi-skilling (Tremblay and De Sève, 1996; Tremblay and Rolland, 1998, 2000). Telework should not be allowed to intensify this segmentation or polarization of working conditions between men and women.

Even though the advantages of telework in terms of the balance between work and family responsibilities are mainly related to flexible schedules and the reduction of travel time, which are often important for employees and managers, female and male, the organization should consider that potential conflict situations exist, particularly for female teleworkers. The latter may in fact have to manage the expectations of family members about their ability to participate more in household tasks because they work at home. Some of the women in our study pointed out that this situation had been the subject of negotiation within the family, with both spouses and children. Organizations must, therefore, be particularly vigilant about making future teleworkers aware of this situation and making sure that teleworkers do not try to "reconcile the irreconcilable" (to use the title of a video on the work-family balance). Telework must not serve as a substitute for adequate and appropriate childcare measures or flexible schedules that help reconcile work and family responsibilities.

\section{REFERENCES}

Akyeampong, E.B. and R. Nadwodny (2001). Evolution du lieu de travail: le travail à domicile. Perspective. Ottawa: Statistics Canada publication No 75-001-XPF. Pp.33-46. (also available in English).

Akyeampong, E.B. (1997). Work arrangements ; 1995 overview. Perspectives on labour and income. Spring. Ottawa: Statistics Canada publication No 75-001-XPE.pp. 48-52

Akyeampong, E.B. and J. Siroonian (1993). Work arrangements of Canadians- an overview. Perspectives on labour and income. Autumn. Ottawa: Statistics Canada publication No 75-001XPE.pp. 8-10.

Bangemann, Martin (1994). L'Europe et la société de l'information planétaire. Recommandation au Conseil européen, CCE, Bruxelles.

Bellemare, D., L. Poulin Simon and Diane-Gabrielle Tremblay (1998). Le paradoxe de l'âgisme dans une société vieillissante; enjeux et défis de gestion. Montréal: Ed. St-Martin, 265 p.

Benchimol, Guy (1994). L'entreprise délocalisée. Paris: Ed. Hermès, pp. 67-103.

Boivin, C., Rivard, S., Aubert, B. A. (1996). Le télétravail, un phénomène en émergence. Gestion, Vol. 21, No. 2, pp. 68-75.

Bussière,Y., Lewis, P., Thomas, C.(1999). L’impact du télétravail et de la réorganisation du temps de travail sur la mobilité et les besoins en transport dans les régions de Montréal et de Québec; Analyse prospective, INRS urbanisation, GRIMES/CRAD, Institut d'urbanisme, Québec, 173 p. 
CEE (1991). Les enjeux sociaux de la bureautique en Europe. Europe sociale, Supplément 5.91, CEE, Luxembourg.

Chapman, A. J., Sheehy, N.P., Heywood, S., Doolley, B., Collins, S.C. (1995). The Organizational Implications of Teleworking in Cooper, C. L., Robertson, I. T. (ed.), International Review of Industrial and Organizational Psychology, No. 10, John Wiley \& Sons Ltd., pp. 229248.

Christensen, K. E. (1987). Impacts of computer-mediated home based work on women and their families. Office: Technology and People, 3, 211-230.

Côté-O'Hara, J. (1992). Sending them Home to Work; Telecommuting and Work-Family Conflict: A Comparative Analysis, Information Systems Research, Vol. 3, No. 2, pp.173-190.

Felstead, A. (1996). Homeworking in Britain: the national picture in the mid-1990s, in Industrial Relations Journal, 27:3, September 1996, 225-238.

Felstead, A. and N. Jewson (2000). In Home, at Work. Towards an Understanding of Homeworking. London: Routledge, 196 p.

Felstead, A. and N. Jewson (1997). Notes and Issues: Researching a Problematic Concept: Homeworkers in Britain. In Work, Employment and Society. Vol. 11, No. 2, pp. 327-346.

Felstead, A., N. Jewson, S. Walters and A. Phizacklea (2000). Measuring the Extent and Characteristics of Working at Home in the UK. Paper presented at the International Working Party on Labour Market Segmentation Conference, Manchester School of Management. UMIST. July 12-15, 2000,13 p.

Felstead, A., N. Jewson, A. Phizacklea and S. Walters (2000). A Statistical Portrait of Working at Home in the UK. Evidence from the Labour Force Survey. Discussion paper March 23, 2000. 55 p.

Greengard, S. (1994). Making a Virtual Office a Reality. Personnel Journal, Vol.73, No. 9, pp. 66-79

Hafer, M. (1992). Telecommuting: An Alternate Route to Work, Vol. 1, Step by Step Guide, Washington State Energy Office.

Heilmann, W. (1988). The Organizational Development of Teleprogramming in Telework: Present Situation and Future Development of a New Form of Work Organization, W.B. Korte, S. Robinson and W. J. Steinle (ed.), Elsevier Science Publishers B.V, North-Holland, pp39-58.

Hequet, M.(1994). How Telecommuting Transforms Work, Training, Vol. 31, No. 11, November, pp. 56-61.

Huws, U., Korte, W. B., Robinson, S. (1990). Telework: Towards the Elusive Office, John Wiley, Information Systems Series, John Wiley \& Sons, 266 p. 
Katz, A. I, (1987).The Management, Control, and Evaluation of a Telecommuting Project: A Case Study, Information \& Management, Vol. 13, pp. 179-190.

Konradt, U., Schmook, R., Mälecke, M. (2000). Impacts of Telework on Individuals, Organizations and Families - a critical review. International Review of Industrial and Organizational Psychology, Vol. 15, ed. by C. L. Cooper and I. T. Robertson, 63-98.

Korte, W.B. (1988). Telework -Potential, Inception, Operation and Likely Future Situation in Telework, Prest Situation and Future Development of New Form of Work Organization, W. B. Korte, S. Robinson and W. J. Steinle (eds). Elsevier Science Publishers B.V, North Holland, pp. 159-175.

Kurkland, Nancy B., Bailey, Diane E. (1999): Telework: The Advantage and Challenge of Working Here, There, Anywhere, and Anytime, Organizational Dynamics, Autumn, pp. 53-68.

Lemesle, R. M. and J. C. Marot (1996). Le télétravail. Paris: PUF. Coll. Que sais-je?

Nadwodny, R. (1996). Canadians working at home. Canadian Social Trends. Spring. Pp. 16-20.

Nilles, J. M., Roy Carlson Jr. et al.(1976). The Telecommunications-Transportation Trade-off: Options for Tomorrow. A Willey Interscience Publication, John Wiley \& Sons, 196 p.

Olson, M.H. (1989). Work at home for computer professionals: Current attitudes and future prospects. ACM Transactions on Office Informations Systems, 7, 317-338.

Pichault, F. et S. Grosjean (1998). Du télétravail au travail à distance; les modèles contingent et politique en question. Liège, Belgique: Fonds national de la recherche collective. $146 \mathrm{p}$.

Pinsonneault, A. (1996). Le télétravail: état de la question. Gestion, Vol. 21, No. 2 (June), pp. 6667.

Pratt, J. (1984). Home Teleworking: A study of its pioneers. Technological Forecasting and Social Change, 25,1-14.

Statistics Canada (1998). The Daily. March 17 th. Ottawa: Statistics Canada no 11-001-E.

St-Onge, S., V. Haines, and H. Sevin (2000). L'influence de l'appui du supérieur hiérarchique, des collègues et des dirigeants d'entreprises sur le succès en télétravail. Relations industrielles. Vol. 55, no 3. Pp. 414-448.

Tremblay, Diane-Gabrielle (2001). Le télétravail: définitions et enjeux. Dans Télétravail; concilier performance et qualité de vie. Montréal: IQ collectif et Cefrio. Pp. 23-32.

Tremblay, Diane-Gabrielle (2001a). Work-Family Balancing and Interest for Working Time Reduction: Some Results from a Research conducted in Canada. In Marshall, Victor and Anil Verma (2001, eds.). Restructuring Work and the Life Course. University of Toronto Press. 
Tremblay, Diane-Gabrielle et Catherine Vaillancourt-Laflamme (2000). Conciliation emploifamille et aménagement du temps de travail. Research Report 116 p.

Tremblay, Diane-Gabrielle and Charles-Henri Amherdt (2000). La vie en double : les obstacles organisationnels et socio-culturels à la participation des pères et des mères à la conciliation emploi-famille. Research Report. 100 p.

Tremblay, D.-G. and D. Rolland (2000). Labour regime and industrialisation in the knowledge economy; the Japanese model and its possible hybridisation in other countries. Labour and Management in Development Journal. No 7. Brisbane : The Australian National University. P. 120.

Tremblay, Diane-Gabrielle and Daniel Villeneuve (1998). L'aménagement et la réduction du temps de travail: les enjeux, les approches, les méthodes. Montréal: Éditions St-Martin, 362 p.

Tremblay, Diane-Gabrielle and David Rolland (1998). Gestion des ressources humaines; typologies et comparaisons internationales. Québec: Presses de l'université du Québec, 415 p.

Tremblay, Diane-Gabrielle and Daniel Villeneuve (1997). Aménagement et réduction du temps de travail: réconcilier emploi, famille et vie personnelle. Loisir et société, Vol. 20, No. 1, Sept. 1997. Québec: PUQ, pp. 1-51.

Tremblay, Diane-Gabrielle (1997). Economie du travail. Les réalités et les approches théoriques. Montréal: Editions Saint-Martin, 586 p.

Tremblay, Diane-Gabrielle and Monique K. de Sève (1996). Formes changeantes et persistantes de la division sexuelle du travail; les résultats d'une enquête auprès d'une centaine de salariés dans dix entreprises québécoises. Recherches féministes. Vol. 9, No. 1, 81-104.

Vandercammen, Marc (1996.). Télétravail, Institut wallon d'études de recherches et de formation. Bruxelles. 